\title{
The Art of Betrayal: The Secret History of MI6, Life and Death in the British Secret Service. By Gordon Corera. New York, NY: Pegasus Books, 2013.
}

Ed J. Hagerty, Ph.D. American Military University

Follow this and additional works at: https://digitalcommons.usf.edu/jss pp. 95-97

\section{Recommended Citation}

Hagerty,, Ed J. Ph.D.. "The Art of Betrayal: The Secret History of MI6, Life and Death in the British Secret Service. By Gordon Corera. New York, NY: Pegasus Books, 2013.." Journal of Strategic Security 7, no. 3 (2014) : 95-97. DOI: http://dx.doi.org/10.5038/1944-0472.7.3.6 Available at: https://digitalcommons.usf.edu/jss/vol7/iss3/7

This Book Review is brought to you for free and open access by the Open Access Journals at Digital Commons @ University of South Florida. It has been accepted for inclusion in Journal of Strategic Security by an authorized editor of Digital Commons @ University of South Florida. For more information, please contact digitalcommons@usf.edu. 
The Art of Betrayal: The Secret History of MI6, Life and Death in the British Secret Service. By Gordon Corera. New York, NY: Pegasus Books, 2013. 
Hagerty,: The Art of Betrayal

\section{The Art of Betrayal: The Secret History of MI6, Life and Death in the British Secret Service. By Gordon Corera. New York, NY: Pegasus Books, 2013. ISBN: 978-1-60598-398-1. Photographs. Notes. Index. Pp. 496. \$35.00.}

Readers are generally well advised to exercise some caution with books whose titles purport that the contents comprise "The Forgotten Tale of ...., "The Lost Story of ...," or in this case "The Secret History of. ..." It is not unusual for readers of such works to soon discover that the intriguing titles are the work of the author's or the publisher's overactive imagination. That's not quite the case here, but in all fairness to readers, the book is also not exactly what the title would lead one to believe. Reflecting the author's journalistic background, the book is not actually a history of MI6, but a far more selective rendering of stories that might enable one to extrapolate more broadly to gain a better sense of the history of Britain's overseas intelligence service, MI6.

Journalist Gordon Corera is security correspondent for the BBC. Educated at Oxford and Harvard, Corera hosted a three-part series on BBC Radio in 2009 entitled "MI6: A Century in the Shadows." As a result of that and his years of reporting on intelligence matters, Corera had enviable access to some of Britain's top officials in MI6 and participants in some of its more notorious escapades. That access clearly informed the contents of his book as well. The style of the book will mostly appeal to those with little familiarity with the topic or with the world of intelligence in general, or those simply looking for a good, factual spy tale. The dramatic storytelling style of the book makes for a compelling read, but it is not the type of scholarly treatment this subject justly deserves, and it is somewhat marred by the author's limited perspective on the topic. Still, there are reasons it's worth reading, as described below.

The book follows a mostly chronological line stretching from post-World War II Vienna to modern day Southwest Asia. Drawing on interviews and first-hand accounts from participants, Corera constructs the tale of MI6 during those years by telling the story of the spies and spy masters who played significant roles throughout them. An important sub-theme woven throughout the book is the relationship between Britain and its American cousins. In the aftermath of the Second World War, Britain was faced with an unprecedented financial crisis that hampered the operational capability of its security services just as the threat of Communist domination supplanted that of National Socialism. It was the Americans and the CIA that stepped into the breach, forever changing the balance of power between British and U.S. intelligence services just as the war had ushered in the decline of the British Empire and the rise of a new American superpower. In Corera's view, both nations' intelligence agencies thus shared in the successes and failures, the latter marked most prominently by the treachery of Kim Philby, which Corera notes highlighted the problems in operations and "the whole culture of Anglo-American intelligence" (p. 67).

Corera carefully traces the story of Oleg Penkovsky, one of the most important Cold War Russian intelligence officers to spy for the West. Penkovsky was found out, tried, and probably executed by the Soviets in 1963, and it seems clear from the tale Corera relates that the case was still marked by the same carelessness and bungling that plagued western intelligence at the start of the Cold War era. The 
case marked a turning point in MI6's history. Remarkably, according to the author, it restored confidence within the service and established a new era of professionalism for the future. Given the dreadful mismanagement on the part Penkovsky's handlers and the intelligence agencies involved, this is a rather dubious conclusion. That there was no internal inquiry remarked on, combined with the fact that the Penkovsky case enhanced the careers of many of those involved, seems to indicate the existence of a far more serious institutional weakness in the service. The information Penkovsky provided allowed MI6 to turn a sow's ear into a silk purse, but a closer examination of the handling of their most valuable source raises some serious questions about the service's capabilities at that time.

By the time the author moves on to the post-9/11 era, the story becomes less about MI6 per se, and instead about the interplay between Britain's Joint Intelligence Committee, its government on the whole, and the relationship between the United States and its closest ally. That discussion provides the context for the events that are illustrated most prominently by the intelligence failures leading to the invasion of Iraq. The impression conveyed is that of an MI6 that throughout its history was consistently threatened and insecure, never more so than after the collapse of the Soviet Union when the removal of the threat of communist domination left the service questioning its relevance. The events after 9/11 "offered delivery from those fears" (p. 364).

It must be recalled that it was widely accepted in U.S. intelligence circles that an increasing reliance on technical and electronic intelligence collection methods and a decrease in HUMINT capability put us at a disadvantage in Southwest Asia. The British view leading up to the invasion of Iraq, however, blamed the fact that Iraq had been relegated to the status of a backwater, low-priority target until 9/11 boosted its importance. Previously reliable MI6 sources being aggressively tasked to provide information about weapons of mass destruction (WMD) in Iraq thus began to over-reach their usual access levels. That, combined with frantic attempts to enhance its role in rapidly unfolding world events, led MI6 leaders to elevate unreliable, unproven intelligence straight to Downing Street with little or no vetting through the services assessment staff. Prime Minster Tony Blair's eagerness to partner with the United States and play a co-equal role in a global war on terror meant that such shoddily vetted information was being shared in ways that were in no way warranted based on its reliability. Later, many of the MI6 sources denied ever having made any of the statements about WMDs that were attributed to them and which helped both the United States and Great Britain justify the war in the first place.

The book ends with a brief discussion of MI6's involvement in Libya, but the overall theme of foul ups prevails. The entire impression conveyed in this work is that while the history of MI6 can be marked by stories of individual agents' bravery and successes, the service's reputation as a whole is less stellar. The importance of accurate intelligence, no matter how it is collected, and the appropriate analysis and vetting of that information cannot be underestimated in terms of its contributions to foreign policy strategy and decision making. If the trend established throughout this book still prevails, Americans and Britons alike have good reason to fear that their governments might be making worldchanging decisions on the basis of flawed information or interpretations. 
While it might not be the final word on the history of MI6 as an organization, Gordon Corera has made a unique contribution to the study of that agency and the world of intelligence through this useful, thought-provoking, and well-written book. He illustrates the close ties between the United States and Great Britain in that area, but perhaps most usefully he documents what can go wrong when intelligence agencies and their governments establish too close a relationship, and where the collection and dissemination of information is based on desired political outcomes rather than practical realities.

Edward J. Hagerty, American Military University 